\title{
The impact of shelterbelts in North Island East Coast dryland regions
}

\author{
M.F. HAWKE ${ }^{1}$, A.G. GILLINGHAM ${ }^{2}$, M. GRAY ${ }^{3}$ and M. DEAN ${ }^{4}$ \\ ${ }^{1}$ AgResearch, Rotorua \\ ${ }^{2}$ AgResearch, Palmerston North \\ ${ }^{3}$ AgResearch, Poukawa, Hastings \\ ${ }^{4}$ Forest Research, Rotorua
}

\begin{abstract}
Shelterbelts are a feature of the New Zealand landscape and in the dryland East Coast regions of the North Island, are seen in a diversity of planting patterns, species and silvicultural practices. To date, their economic benefits have not been assessed, partly because of the difficulty in evaluating the many interrelated pasture, soil, animal and forestry factors. Recent shelterbelt research in New Zealand has been conducted as a collaborative approach by AgResearch, Forest Research and Hort Research. Results of pasture, soil and tree measurements in the East Coast region indicate that shelterbelts, however managed, do not significantly increase pasture production in the sheltered zone. The competitive effects of trees reduce soil moisture in zones close to the shelter, which also encourages the accumulation of dung and urine nutrients in this zone by animals seeking protection. The modification in resting patterns as a result of shelter may be reflected in improved animal welfare and production but this was not measured. The value of timber from shelterbelts on the East Coast indicates that they have a role in diversifying farming income and offering a modified land use, which will help to sustain productive farming practices.
\end{abstract}

Keywords: livestock, log value, pasture production, Pinus radiata, shelter, shelterbelts, soil moisture, soil nutrients, wood yields

\section{Introduction}

Interest in the use and value of shelterbelts on pastoral farms has increased in recent years in New Zealand. Shelterbelts are a feature of most landscapes and their roles are multi-fold. They generally aim to reduce wind speed and provide protection for livestock. Benefits may also include erosion control, animal welfare, crop protection, aesthetic improvement and cash returns. The design and management of shelterbelts has often been for specific purposes e.g., to provide protection from a predominant wind direction or for timber yields, but not for multi-purposes. In the dryland areas of the North Island, specifically Hawke's Bay and Wairarapa, shelterbelts have been planted primarily to reduce the effects of strong winds. A number of tree species have been used, but most studies have been with Pinus radiata which has a recognised commercial value and is widely planted (Hawke \& Tombleson 1993).

Shelterbelt research in New Zealand currently focuses on quantifying both the shelter effects and the timber production aspects. It is a collaborative programme, developed by AgResearch, Forest Research and HortResearch. AgResearch has monitored the shelter effects on pastoral parameters, Forest Research has measured the growth of a range of shelterbelts and is developing a shelterbelt decision support model, and HortResearch has focussed on understanding the effects of windbreak design on a range of microclimate parameters.

An earlier study (Hawke \& Tombleson 1993) of 1 year's pasture data from a shelterbelt located at Matea, near Taupo indicated that there was a $15 \%$ increase in pasture production at a distance equal to 0.7 times the height (h) from the shelterbelt, but on average there was a slight decrease in pasture growth in the sheltered, versus the open pasture zone. Timber yields were predicted to be $2300 \mathrm{~m}^{3} / \mathrm{km}$ of shelterbelt with a net value of $\$ 130000 / \mathrm{km}$, at age 28 years.

This paper presents pasture production data from two shelterbelt sites in the dry East Coast regions of the North Island and interprets the results in relation to shelterbelt design and management. Predicted timber yields and values are based on several Hawke's Bay measurement plots, and some effects of shelterbelts on livestock farming are discussed.

\section{Trial details and methods}

\section{Hawke's Bay}

Two north west/south east (NW/SE) orientated shelterbelts were measured at Poukawa AgResearch Research Station, 14 km south of Hastings from 19961999 (Figure1a). The shelterbelts were planted parallel and $320 \mathrm{~m}$ apart in 1980 and were $21-25 \mathrm{~m}$ in height over the measurement period. The north shelterbelt was comprised of a single row of unpruned, Pinus radiata, and the south shelterbelt was formed by a 
double row of unpruned, Pinus radiata. The soil type was Matipiro sandy loam (YGE) and the average annual rainfall was $770 \mathrm{~mm}$. Pasture between the shelterbelts consisted of $10 \%$ ryegrass (Lolium perenne), 10\% legumes (Trifolium repens and Trifolium subterraneum) and $80 \%$ other grasses. The paddock was rotationally grazed with sheep and young dairy cattle at a stocking rate of $10 \mathrm{su} / \mathrm{ha}$. One set of measurements was taken on the southerly aspect of shelterbelt 1 (Table 1), and the other on the northerly aspect of shelterbelt 2 .

Two pasture cages $\left(0.5 \mathrm{~m}^{2}\right)$ were located $30 \mathrm{~m}$ apart at each of the distances $5 \mathrm{~m}, 10 \mathrm{~m}, 20 \mathrm{~m}, 40 \mathrm{~m}, 80 \mathrm{~m}$ and $120 \mathrm{~m}$ from each shelterbelt representing zones at $0.25 \mathrm{~h}, 0.5 \mathrm{~h}, 1 \mathrm{~h}, 2 \mathrm{~h}, 4 \mathrm{~h}$ and $6 \mathrm{~h}$. The mid-way point at $160 \mathrm{~m}(8 \mathrm{~h})$ represented open pasture. Pasture production was measured by the trim technique (Piggott 1986) on three occasions each year from a $0.1 \mathrm{~m}^{2}$ quadrat within each cage. Dry matter production was calculated from each cage after separating out any pine needles present.

Soil samples (0-75 $\mathrm{mm}$ depth) were taken in December 1996 as a bulk sample at each of $5 \mathrm{~m}, 10 \mathrm{~m}$, $20 \mathrm{~m}, 80 \mathrm{~m}$ distance from the shelterbelt on each aspect, and at $160 \mathrm{~m}$, and subjected to AgResearch Quick Test Analysis.

Soil moisture content by weight was calculated from duplicate samples of bulked, $75 \mathrm{~mm}$ depth cores taken at the range of distances in November 1997 and April 1998, which represented drying out and a drought situation respectively.

\section{Wairarapa}

A single row, northeast/southwest orientated (NE/SW) shelterbelt of Pinus radiata with a second row of Leyland cypress to provide low shelter on the NW side, was measured on a property at Wiltons Road, $3 \mathrm{~km}$ south of Masterton from 1993-1996 (Figure1b). The shelterbelt was planted in 1985 and was $10-13 \mathrm{~m}$ in height over the period of measurement. The property is flat and experiences strong, drying, NW winds in the summer months, and cold southerly winds in winter. The soil type was Tauherenikau stony silt loam and the district average annual rainfall was $1000 \mathrm{~mm}$. The pasture on both aspects was measured and consisted of about $25 \%$ white clover (Trifolium repens), $7 \%$ weeds and $68 \%$ grasses. Grazing was with dry stock at a wintering stock carrying capacity of $12 \mathrm{su} / \mathrm{ha}$. Measurements on the SE aspect were at the same range of distances as at Hawke's Bay but also at $200 \mathrm{~m}(16.8 \mathrm{~h})$ to represent the open pasture zone. Measurements on the NW aspect were to $120 \mathrm{~m}(10.1 \mathrm{~h})$.

In 1993, two pasture measurement cages were located $10 \mathrm{~m}$ apart at each of the distances on both aspects of the shelterbelt. From 1994-1996, the number
Figure 1a Plan of Poukawa shelterbelts

Poukawa

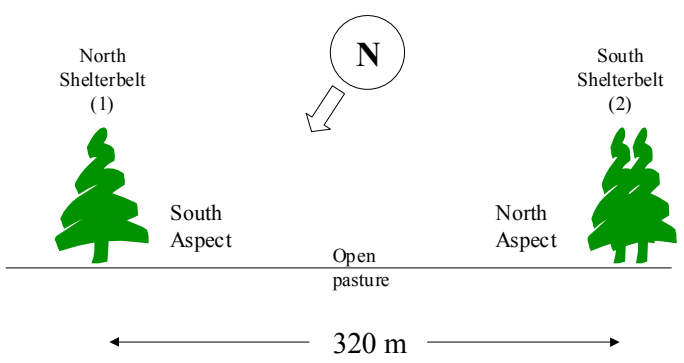

Figure 1b Plan of Masterton shelterbelt.

Masterton

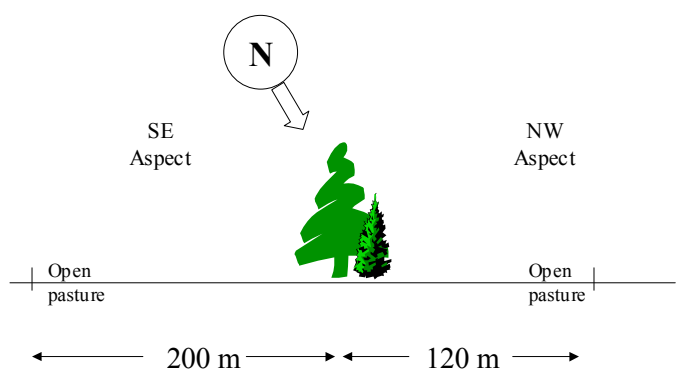

of cages was increased to three at each distance. Pasture growth was measured at 4-6 times each year, using the same technique as at Hawke's Bay.

A bulked soil sample $(0-75 \mathrm{~mm}$ depth) taken at each distance on both aspects in December 1994, was subjected to AgResearch Quick Test Analysis. Soil moisture content by weight was calculated from bulked $100 \mathrm{~mm}$ depth cores taken at each distance in February and in December 1994.

The data from both sites was analysed using Flexi 2.4a (Bayesian smoothing programme) and the fitting of a spline with an asymptote feature (Upsdell 1985).

Optical porosity of each shelterbelt was measured in two dimensions as the visible spaces within a shelterbelt when viewed as a silhouette (Horvath et al. 1997).

\section{Timber production}

The financial returns from the timber grown in each shelterbelt was estimated by using the forest stand level decision support system STANDPAK (Whiteside 1990). Tree diameter and height data from permanent sample plots installed in the shelterbelt at Masterton, and the shelterbelts on either side of the study area at Poukawa, were used to calibrate and initialise a shelterbelt growth 
prediction model (TBELT98). The shelterbelts were grown forward to age 28 years and the recoverable volume of logs by grade estimated. As log quality parameters estimated by the model are based on plantation grown trees, user defined inputs such as branch index and sweep were altered to better account for the open grown type of trees found in shelterbelts. The sweep and branch index settings were adjusted based on branch data collected from earlier studies on shelterbelts in Canterbury and the Central Plateau (Tombleson 1988).

Log grade specifications were obtained from two Hawke's Bay log buyers. Log prices were sourced from the 12 quarter average prices published by MAF (Anon). These were used to calculate the projected revenue from each shelterbelt.

A description of the three shelterbelts is contained in Table 1 .
Figure 2 Poukawa: the effect of distance and aspect from shelterbelts on adjacent annual pasture production $(\mathrm{kg}$ $\mathrm{DM} / \mathrm{ha}$ ).Dotted lines indicate $95 \%$ confidence range from the mean.

Table 1 Shelterbelt descriptions.

\begin{tabular}{|c|c|c|c|c|c|c|}
\hline $\begin{array}{l}\text { Shelterbelt } \\
\text { location }\end{array}$ & Orientation & $\begin{array}{l}\text { No of } \\
\text { rows }\end{array}$ & $\begin{array}{l}\text { Between } \\
\text { row } \\
\text { spacing } \\
(\mathrm{m})\end{array}$ & $\begin{array}{l}\text { Within } \\
\text { row } \\
\text { tree } \\
\text { spacing } \\
\text { (m) }\end{array}$ & $\begin{array}{l}\text { Between } \\
\text { fence } \\
\text { width } \\
\text { (m) }\end{array}$ & $\begin{array}{c}\text { Optical } \\
\text { porosity } \\
(\%)\end{array}$ \\
\hline Poukawa 1 & NW/SE & 1 & - & 2.0 & 4.0 & 23.3 \\
\hline Poukawa 2 & NW/SE & 2 & 2.6 & 1.8 & 6.6 & 23.6 \\
\hline \multirow[t]{2}{*}{ Masterton } & NE/SW & 1 & - & 2.5 & 4.5 & 20.2 \\
\hline & $\begin{array}{c}\text { Current } \\
\text { age } \\
\text { (yrs) }\end{array}$ & $\begin{array}{c}\text { Site } \\
\text { index } \\
(\mathrm{m})\end{array}$ & $\begin{array}{c}\text { Tree } \\
\text { stocking } \\
\text { (stems/km) }\end{array}$ & $\begin{array}{l}\text { Mean } \\
\text { DBH } \\
(\mathrm{cm})\end{array}$ & $\begin{array}{c}\text { Mean } \\
\text { top } \\
\text { height }(\mathrm{m})\end{array}$ & $\begin{array}{c}\text { Pruned } \\
\text { height } \\
\text { (m) }\end{array}$ \\
\hline Poukawa 1 & 19 & 19.9 & 512 & 38.7 & 24.9 & 0 \\
\hline Poukawa $2^{*}$ & 19 & 22 & 1025 & 35.2 & 21 & 0 \\
\hline Masterton & 15 & 18.5 & 443 & 29.5 & 15.7 & 5.4 \\
\hline
\end{tabular}

The financial return per kilometre of shelterbelt length was calculated using the total shelterbelt width from fence to fence and a land value of \$3500/ha. A list of user inputs used for the economic analysis is contained in Appendix 1.

\section{Results}

\section{Pasture production}

The average annual pasture production at Poukawa was lower close to the shelterbelt on the southern aspect, but on the northern aspect the decline in grass and legume growth was masked by vigorous weed growth during winter and early spring (Figure 2). The low level of total annual pasture production was due to the effects of summer-autumn drought.

At the Masterton site, a depression in pasture growth occurred adjacent to the shelterbelt at the $5 \mathrm{~m}$ distance on both aspects (Figure 3) but again was more marked on the south aspect. There was a significant $(\mathrm{P}>0.05)$ increase in dry matter production in the $5-80 \mathrm{~m}$ distance on the SE aspect at both sites, then a small decline with further distance from shelter. This effect was not apparent on the NW aspect (Figure 3).

\section{Soil nutrient status}

Because soil nutrient status was measured on a bulk sample at each distance the results can only be used to indicate general nutrient levels or trends. At Poukawa, soil P, K and $S$ levels were all elevated close to the shelter on the northerly aspect, but only soil $\mathrm{K}$ was higher on the southerly aspect (Table 2).

Figure 3 Masterton: the effect of distance and aspect from shelterbelt on adjacent annual pasture production $(\mathrm{kg}$ $\mathrm{DM} / \mathrm{ha}$ ). 
At Masterton, soil $\mathrm{K}$ levels were higher and soil $\mathrm{pH}$ lower, close to the shelterbelt, especially on the SE aspect. Magnesium and sulphur levels were similar across all distances. Soil $\mathrm{P}$ was highest at the furthest distance on both aspects (Table 2).

Table 2 Soil nutrient levels adjacent to shelterbelts at Masterton and Poukawa.

\begin{tabular}{lrrrrrrr}
\hline Masterton & & \multicolumn{7}{c}{$-\mathbf{c}$ Soil Quick Test Units } & \\
SE Aspect & Distance $(\mathrm{m})$ & $\mathrm{Ca}$ & $\mathrm{K}$ & $\mathrm{P}$ & $\mathrm{Mg}$ & $\mathrm{S}$ & $\mathrm{pH}$ \\
& 5 & 9 & 14 & 12 & 21 & 6 & 5.2 \\
& 10 & 13 & 4 & 11 & 23 & 4 & 5.8 \\
& 20 & 12 & 4 & 8 & 22 & 3 & 5.8 \\
& 40 & 13 & 7 & 11 & 22 & 6 & 5.7 \\
& 80 & 11 & 6 & 13 & 19 & 4 & 5.7 \\
& 120 & 9 & 4 & 12 & 15 & 3 & 5.7 \\
& 160 & 8 & 6 & 11 & 17 & 4 & 5.6 \\
& 200 & 8 & 13 & 18 & 22 & 5 & 5.4
\end{tabular}

NW Aspect

$\begin{array}{rrrrrrr}5 & 6 & 8 & 10 & 19 & 4 & 5.4 \\ 10 & 11 & 7 & 9 & 19 & 9 & 5.8 \\ 20 & 10 & 5 & 9 & 19 & 5 & 5.6 \\ 40 & 10 & 8 & 11 & 20 & 4 & 5.7 \\ 80 & 11 & 5 & 10 & 20 & 5 & 5.8 \\ 120 & 7 & 7 & 18 & 18 & 6 & 5.4\end{array}$

Poukawa Sth Aspect

\begin{tabular}{lrrrcccc} 
& 5 & 10 & 8 & 14 & $*$ & 7 & 6 \\
& 10 & 8 & 3 & 16 & $*$ & 5 & 5.8 \\
Mid-zone & 20 & 9 & 4 & 18 & $*$ & 7 & 6 \\
Nth Aspect & 80 & 8 & 5 & 13 & $*$ & 6 & 5.7 \\
& 160 & 8 & 5 & 19 & $*$ & 9 & 5.8 \\
& 5 & 10 & 35 & 92 & $*$ & 32 & 5.9 \\
& 10 & 10 & 5 & 15 & $*$ & 8 & 5.5 \\
& 20 & 8 & 4 & 9 & $*$ & 8 & 5.7 \\
& 80 & 9 & 3 & 9 & $*$ & 7 & 5.8 \\
\hline
\end{tabular}

* $=$ Not measured

${ }^{1}$ Cornforth and Sinclair 1982

\section{Soil moisture}

At Poukawa, soil moisture levels in November were lower at the $5 \mathrm{~m}$ distance on both aspects, whereas in the April sampling, soil moistures were marginally higher at $5 \mathrm{~m}$, particularly on the southern aspect (Figures 4 \& 5). In December 1994 at Masterton, in a drying out phase, there was a pattern of increasing soil moisture on both aspects as distance from shelterbelt increased (Figure 6). However, in February 1994, under rewetting soil conditions, only the soil at $5 \mathrm{~m}$ distance from the shelterbelt was drier than open pasture (data not shown).

\section{Timber production}

The estimated mean tree diameter at breast height (DBH) at age 28 years was similar for all three shelterbelts (Table 1). The two row shelterbelt at Poukawa was predicted to have a mean $\mathrm{DBH}$ of $42 \mathrm{~cm}$, the single row shelterbelt at Poukawa $43.1 \mathrm{~cm}$, and the pruned, single
Figure 4 Poukawa: the effects of shelterbelts on soil moisture\% in a drying out phase (November 1997).

Figure 5 Poukawa: the effects of shelterbelts on soil moisture\% in a drought (April 1998).

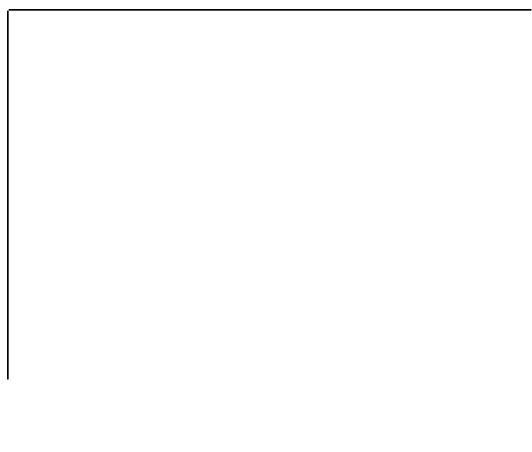

Figure 6 Masterton: the effect of a shelterbelt on soil moisture\% in a drying out phase (December 1994).

row shelterbelt at Masterton $44.1 \mathrm{~cm} \mathrm{DBH}$. There was a wide range in merchantable volume from the three shelterbelts. The two row shelterbelt at Poukawa occupied about $66 \%$ more area than the associated single row 
shelterbelt (Table 1), and produced almost twice as much wood volume $\left(1067 \mathrm{~m}^{3} / \mathrm{km}\right)$, as the single row unpruned, belt $\left(556 \mathrm{~m}^{3} / \mathrm{km}\right)$, and 2.6 times the volume of the single row pruned shelterbelt $\left(412 \mathrm{~m}^{3} / \mathrm{km}\right)$ (Table 3).

Table 3 Estimated merchantable log volume and financial return per kilometre of shelterbelt at age 28 years.

\begin{tabular}{lrccc}
\hline Log grade & $\begin{array}{r}\text { Volume } \\
\left(\mathrm{m}^{3} / \mathrm{km}\right)\end{array}$ & $\begin{array}{c}\text { Estimated } \\
\text { value at mill } \\
(\$ / \mathrm{km})\end{array}$ & $\begin{array}{c}\text { Net Present } \\
\text { Value/km/yr } \\
(\mathrm{NPV})\end{array}$ & $\begin{array}{c}\text { Internal Rate } \\
\text { of return } \\
(\% / \mathrm{yr})\end{array}$ \\
\hline Poukawa double row, & & & & \\
unpruned, shelterbelt & 0 & 0 & & \\
Pruned logs & 204 & 15602 & & \\
Other sawlogs & 863 & 29338 & & \\
Pulp & 1067 & 44941 & $\$ 2005$ & \\
Total: & & & & \\
Poukawa single row, & & & & \\
unpruned, shelterbelt & 0 & 0 & & \\
Pruned logs & 112 & 8473 & & \\
Other sawlogs & 445 & 15113 & & \\
Pulp & 556 & 23607 & $\$ 64$ & \\
Total: & & & & \\
Masterton single row, & & & & \\
pruned, shelterbelt & 140 & 22086 & & \\
Pruned & 36 & 2772 & & \\
Other sawlogs & 236 & 8036 & & \\
Pulp & 412 & 32893 & $\$ 2006$ & \\
Total: & & & & \\
\hline
\end{tabular}

* at $5 \%$ discount rate

The total value at the mill door of the 2 row, unpruned, Poukawa shelterbelt was $\$ 44941 / \mathrm{km}$ compared with $\$ 32893 / \mathrm{km}$ for the pruned Masterton shelterbelt, and $\$ 23607 / \mathrm{km}$ for the single row, unpruned, Poukawa shelterbelt (Table 3).

\section{Discussion}

The trends in pasture dry matter production on each aspect of both shelterbelts were similar, which was not surprising as the overall optical porosity for the Masterton and Poukawa shelterbelts was also similar at $20.2 \%$ and $23.5 \%$ respectively.

Despite the differences in the specific orientation and the silviculture of the two shelterbelts i.e., the Masterton shelterbelt had Leyland cypress for low shelter with the $P$. radiata pine pruned to $6 \mathrm{~m}$, whereas the Poukawa shelterbelts of $P$. radiata were mechanically side trimmed, neither shelterbelt regime significantly influenced the level of associated pasture production. The Poukawa shelterbelts were 5 years older than the Masterton shelterbelts and therefore may be expected to have greater effects on pasture production. This may have been true at the $5 \mathrm{~m}$ distance due to tree root competition and shading, but did not occur further out into the paddock. These results contrast with results from the higher rainfall, Matea site (Hawke \& Tombleson 1993), where the trees had been pruned to a height of $2 \mathrm{~m}$. This factor may have been responsible for a $15 \%$ increase in pasture production at $10 \mathrm{~m}$, followed by a significant drop at the $20 \mathrm{~m}$ and $40 \mathrm{~m}$ zone. However this has not been further verified.

The evidence from this study is that shelterbelts have not conserved soil moisture in the sheltered zone; in fact, in the zone close to the shelterbelt, competition effects from tree roots (Hawke et al. unpubl. data) reduced soil moisture levels, particularly during the drying out phases at both sites. In a drought situation, there was no beneficial effect of shelter, as the soil suffered uniformly from moisture stress. The absence of shelter effects in dry conditions was similar to that reported by Radcliffe (1985) from Canterbury studies. Earlier studies in the Central North Island/Wairarapa/Southern Hawke's Bay districts in 1995 by the authors (unpubl. data) found that the driest soil was close to the shelterbelt and of increasing relative dryness as shelterbelt height increased.

In areas that receive regular and heavy rainfall, moisture levels throughout the sheltered zone would be expected to be similar, and shelter would not impose differential soil moisture stress conditions.

Soil nutrient accumulation, especially $\mathrm{K}$, in a sheltered environment, has been shown to be an artifact of animal camping (Hawke \& Tombleson 1993; Hawke \& Gillingham 1996; Gillingham \& Hawke 1997). At the Poukawa site, soil nutrient transfer occurred to a much greater degree on the northerly aspect, as evidenced by the relatively high soil $\mathrm{P}, \mathrm{K}$ and $\mathrm{S}$ status in the $5 \mathrm{~m}$ zone. Variations in soil $\mathrm{P}$ and $\mathrm{S}$ content in particular may also be associated with variations in routine fertiliser application and so are not useful in interpreting the effects of animal grazing and camping patterns unless these are marked. A consequence of the animal camping effects, and the amount of bare ground generated at Poukawa, was the weed establishment and growth in the spring of 1997 in the $5 \mathrm{~m}$ zone. Apart from this effect, nutrient accumulation close to the shelterbelt did not result in increased pasture production. The higher soil $\mathrm{K}$ level at the $5 \mathrm{~m}$ distance on the SE aspect of the Masterton shelterbelt compared with that on the NW aspect, suggests that stock may have spent more time sheltering in the shade of NW winds in summer than they did from southerly wind in winter and spring. The opposite situation would therefore 
appear to have occurred at Poukawa as evidenced by the higher soil $\mathrm{K}$ levels at the $5 \mathrm{~m}$ distance on the north aspect.

The quality, and hence value, of the unpruned logs in each shelterbelt was adversely affected by the increase in predicted branch size and the increase in stem sinuosity, compared to equivalent diameter trees growing in a fully stocked plantation environment. Because of the large, predicted branch size and sweep, only a small proportion $(20 \%)$, of the log volume in the unpruned shelterbelts were of sufficient quality to meet the sawlog grade specifications. Therefore, whereas the wood volume from the pruned Masterton shelterbelt was $26 \%$ less than from the unpruned single row shelterbelt at Poukawa, the wood value was 39\% greater, due to the higher value of the pruned logs. Consequently if the 2 row shelterbelt had been planted with genetically superior, physiologically aged cuttings such as are now available, and pruned, the quality of logs, and financial returns could have been significantly improved.

When the growing costs, including the cost of land committed to each shelterbelt, was taken into account using discounted cash flow analysis, the return on capital invested at a $5 \%$ discount rate of return showed that all three shelterbelts have a positive net present value (NPV). The internal rates of return ranged from $5.1 \%$ for the unpruned single row shelterbelt, to $6.4 \%$ for both the single row pruned belt and the 2 row unpruned belt. If this return is applied to an area of $10 \mathrm{~m}$ distance either side of the mature shelterbelts, representing the pasture area most affected by the trees, then the financial return equates to $\$ 1003 / \mathrm{ha} /$ year for the pruned single row shelterbelt at Masterton, and $\$ 911 /$ ha/year for the wider, double row, unpruned shelterbelt at Poukawa. The single row, unpruned shelterbelt at Poukawa returned only $\$ 32 / \mathrm{ha} / \mathrm{yr}$.

The internal rates of return of $5.1-6.4 \%$ shown in this analysis are significantly better than the mean IRR on total farm capital of $1.6 \%$ reported for the sheep and beef industry (New Zealand Sheep and Beef Farm Survey, 1994-95). A small proportion of the total farm capital charges should also be included in the above analysis of shelterbelt financial returns, which would marginally reduce the derived IRR values.

The major limitation to gaining an understanding of the total effects of shelterbelts on farm production and efficiency, is the almost complete absence in New Zealand of measurements of the role of shelter on animal welfare and production. In recent years, there has been an improved understanding of the interaction between animal physiology, environmental influences and animal behaviour in response to external conditions. However, within New Zealand there has been little quantification of benefits of a sheltered environment on animal welfare and production. In a review of shelterbelt research, Gregory (1995) primarily describes overseas work and mentions the benefits from shelter as improvements in growth rates and ovulation rates in sheep and cattle, increased survival of lambs during inclement winter weather and reduced abortions due to hypothermia. In the East Coast dryland regions of the North Island where climatic extremes are a frequent occurrence, a number of shelter benefits for animals are likely, but have yet to be quantified.

\section{Conclusions}

1. The shelterbelts studied did not significantly increase pasture production in the sheltered zone. Competition between trees and pasture close to the shelterbelt reduced pasture growth in that zone.

2. Shelterbelts had no beneficial effect on soil moisture in adjacent areas.

3. Evidence of animal camping, as reflected in nutrient transfer, suggested that shade and shelter were important for stock comfort. However measurements of animal welfare and production effects in this environment are not available.

4. The timber resource at both sites is predicted to provide landowners with a significant income at harvest.

\section{ACKNOWLEDGEMENTS}

The authors gratefully acknowledge the Forest and Farm Plantation Management Cooperative and FRST for funding these projects. Thanks are due also to Don Bell, Wellington Regional Council, for access and assistance with the measurements at Masterton, and AgResearch, for the use of the Poukawa shelterbelts. We also thank John Waller, AgResearch for statistical analysis.

\section{REFERENCES}

Anon. 1999. MAF Log Market Report. In: New Zealand Tree Grower, May 1999. pp. 4.

Cornforth, I.S.; Sinclair, A.G. 1984. Fertiliser and Lime Recommendations for Pastures and Crops in New Zealand. Second Revised Edition, Wellington. New Zealand, MAF. 66pp.

Gillingham, A.G.; Hawke, M.F. 1997. The effects of shelterbelts on adjacent pastures and soils in a temperate climate. Proceedings of the XVIII International Grassland Congress Vol 1: ID 315.

Gregory, N.G. 1995. The role of shelterbelts in protecting livestock: a review. New Zealand journal of agricultural research 38: 423-450. 
Hawke, M.F.; Tombleson, J.D. 1993. Production and interaction of pastures and shelterbelts in the central North Island. Proceedings of the New Zealand Grassland Association 55: 193-197.

Hawke, M.F.; Gillingham, A.G. 1996. Nutrient transfer by livestock adjacent to managed and unmanaged shelterbelts. New Zealand Tree Grower 16(1): 3536.

Horvath, G.C.; Carter, M.A.; Straker, A. 1997. Developing a preliminary model to predict the optical porosity of radiata pine shelterbelts in New Zealand. pp. 130-131. In: Exploring the opportunities for agroforestry in changing rural landscapes. Eds. Lassoie, J.; Buck, L. Proceedings of the $5^{\text {th }}$ North American Agroforestry Conference, Cornell University, Ithaca, NY, August 3-6, 1997.

Piggot, G.J. 1986. Methods for estimating pasture dry matter on dairy farms in Northland. Proceedings of the New Zealand Grassland Association 47: 243247.

Radcliffe, J.E. 1985. Shelterbelt increases dryland pasture growth in Canterbury. Proceedings of the New Zealand Grassland Association 46: 51-56.

Tombleson, J.D.; Inglis, C.S. 1988. Comparison of radiata pine shelterbelts and plantations. pp. 261278. In: Agroforestry symposium proceedings. Ed. Maclaren J.P. FRI Bulletin No 139.

The New Zealand Sheep and Beef Farm Survey 199495. NZ Meat \& Wool Board Economic Service Publication No. 2109. November 1996. pp. 61.
Upsdell, M.P. 1985. Bayesian Inference for Functions. $\mathrm{PhD}$ thesis, Nottingham University.

Whiteside, I.D. 1990. STANDPAK modelling system for radiata pine. pp. 106-111. In: New approaches to spacing and thinning in plantation forestry. Eds. James, R.N.; Tarlton, G.L. Proceedings of IUFRO symposium, FRI bulletin NO. 151. Forest Research Institute, Rotorua.

\section{Appendix 1 \\ Economic details relating to calculation of financial returns}

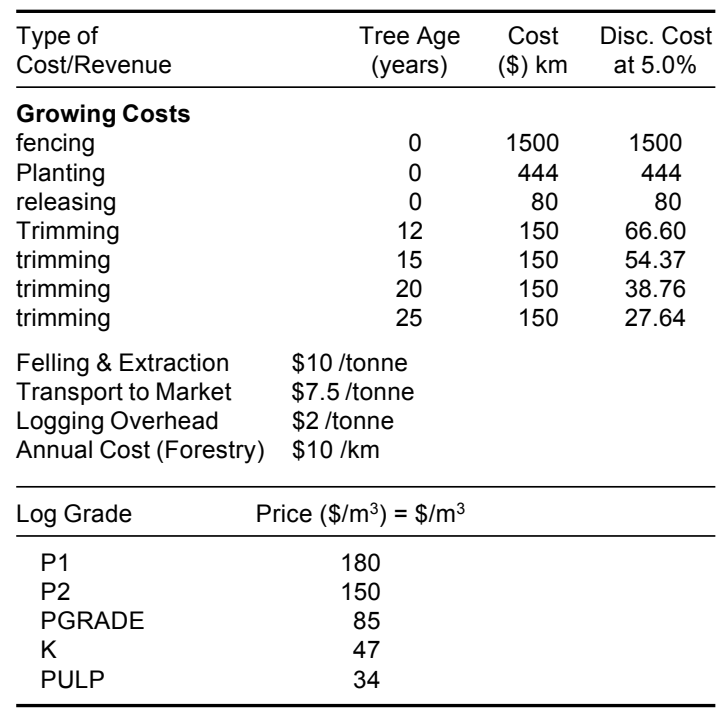


